\title{
A DISCIPLINE PENALTY ENFORCEMENT MODEL TOWARD NEUTRALITY VIOLATION OF GOVERNMENT EMPLOYEES ON REGIONAL ELECTION IN CENTRAL JAVA ${ }^{\Omega}$
}

\author{
Tedi Sudrajat and Sri Hartini \\ Law Faculty of Jenderal Soedirman University Purwokerto \\ E-mail: tedi.unsoed@gmail.com
}

\begin{abstract}
At this time, the implementation of neutrality for government employees are still use the legalistic approach. It doesn't mean that this approach is problematic, but its not relevan when this approach is a self-implementing. That's why the policy is required by casuistry and situational approach, which means that the rule become the basis of law enforcement, while the case resolved by the consideration of the situation and the real reason that occur in the field. In this regard, the government should set standards, procedures and clear criteria against violations of neutrality as a basis for the imposition of penalties that are scalable and doesn't have a double standard. Thats why its necessary to have institution that independent, objective and transparent.
\end{abstract}

Keywords: legal policy, neutrality, law enforcement.

\begin{abstract}
Abstrak
Saat ini penerapan netralitas PNS masih menggunakan pendekatan legalistik. Tidak berarti bahwa pendekatan ini bermasalah, namun tidak tepat ketika terdapat persepsi bahwa peraturan perundangundangan merupakan hal yang self implementing. Karena itulah diperlukan kebijakan penegakan hukuman dengan pendekatan kasuistis dan situasional yang berarti bahwa aturan menjadi basis penegakan hukum, adapun kasus yang terjadi diselesaikan dengan didasarkan pada pertimbangan situasi dan alasan riil yang terjadi di lapangan. Dalam kaitan ini, pemerintah harus membuat standar, prosedur dan kriteria terhadap pelanggaran netralitas sebagai dasar penjatuhan hukuman yang terukur dan tidak memberikan standar ganda. Selain itu diperlukan kelembagaan kepegawaian yang mandiri, obyektif dan transparan dalam penegakan hukuman.
\end{abstract}

Kata Kunci : kebijakan hukum, netralitas, penegakan hukuman.

\section{Introduction}

Political developments in Indonesia through the election mechanism creates a problem of power relations, economics and politics between the state and society. The state as a core of power, authority, and policies were directed to manage the allocation of public goods in the community, whereas in the community itself there are civil and political rights, the power of the masses, the welfare, and others. Participation of political side is as a bridge between the state and society in order to organize a democratic government and led to the welfare. The implication of

$\Omega$ This article is part of a Competitive Research Grant with Title Kebijakan Netralitas Politik Pegawai Negeri Sipil dalam Pemilukada (Studi di Jawa Tengah), funded through scheme research Decentralization competitive grants Jenderal Soedirman University 2015 political participation in governance is the appearance of politicization of bureaucracy in the government system.

In conceptually, the bureaucracy is a system to manage a large organization in order to obtain the efficient management, rational and effective. The authority of law was given to manage the organization in the framework of implementation of tasks in the interests of the people as the sovereign owner and the obligation to devote theirself was given to the Government employees (PNS) within the organization. Based on the filling, positions in government classified into two (2) types: first, career positions were filled by the Government employees who have function as the executor of public policy, public 
servants, adhesives and unifying the nation; second, the political positions are filled through democratic mechanisms through elections of the community representation.

Practically in the area, the implementation of government which is filled by career positions and political office greatly affect the pattern of organizational made in stages (structural). Under its authority, the charging structure of the organization submitted to political office by the results of the elections, which is the Regional Head. Based on Article 53 of Law No. 5 of 2014 on Civil Administrative State, the Head of Regional was delegated by the President to establish the appointment, migration and dismissal of officials besides the official leadership of the highest and the middle head, and officials of the major functional expertise.

The authority delegation, politically has created a role of fund access for political parties in the government area which affecting the govenment employees to participate actively in a practical politics. Eko Prasojo confirms that the impact of this pattern give government employyees who are less competent or if they are competent, but still far from the requirement standard of competence in his post. Most government employees are narrow-oriented mindset as ruler rather than as a public servant, does not have a productive work culture, inefficient and unaccountable, overlapping authority, and it culminate in the unqualified public service. As a result, the presence of PNS seems does not provide an optimum benefit to the community. ${ }^{1}$

In order to anticipate the issues and political interests of neutrality implementation, the government has issued a variety of settings (legal substance), form the legal structure and improve legal culture to minimize the occurrence of the violation. But technically, the application of penalties has not run optimally because: first, usually the setting of the tasks and functions of each enforcement agency neutrality includes the

\footnotetext{
Eko Prasodjo and Laode Rudita, "Undang-Undang Aparatur Sipil Negara; Membangun Profesionalisme Aparatur Sipil Negara", Civil Service-Jurnal Kebijakan dan Manajemen Pegawai Negeri Sipil, Vol. 1 June 2014. Jakarta: Badan Kepegawaian Negara, page 14.
}

Supervisory Board General Elections (Bawaslu), Supervisory Committee Election (Panwaslu), Regional General Election Commission (Election Commission) and Regional Personnel Agency (BKD). The impact is that each institution are mutually relinquish their responsibility; second, the work system of each institution are not integrated and only work on their roles, so the policies in enforcing violations is a sectoral neutrality only; third, many cases are not reported, which indicates that less public control functions. $^{2}$ The weakness of the regulations of the law enforcement on penalties for neutrality violation indicates that the government is still difficult to find the right model. This article comes to suggest the enforcement model of disciplinary penalties for neutrallity violation of government employees in the General Election in Central Java

\section{Problems}

Main problems of this paper are: first, how does the neutrality conception of the government employees and the problematic of the violation neutrality application in General Election? and secondly, what is the appropriate policy models for government employees in the General Election in the region of Central Java which can minimize violations and creating a professional government employees?

\section{Research Method}

Pressure point in this research is an explorative which lead to the realization of the ideal concept in the enforcement of penalties for violation of political neutrality of government employees in the General Election. Overall, the method used is a combination of normative and sociological legal research (mixed research). Normative approach is focused on the discovery of the law principle through legislation and concept approach. To elaborate on the findings of a qualitative research study, problem solving is done

Sri Hartini, Setiajeng Kadarsih, Tedi Sudrajat, "Kebijakan Netralitas Politik Pegawai Negeri Sipil dalam Pemilukada (Studi di Jawa Tengah)", Padjadjaran Jurnal Ilmu Hukum, Vol 1 No. 2, December 2014, Bandung: Law Faculty of Padjadjaran University, page. 539. 
with empirical juridical approach. This is done to clarify the relationship between the legal aspects of the non-legal aspects derived from the application of legal problems.

This research use a primary and secondary data. The primary data source on interviews with elements of BKD, Election Commission (KPUD) and the Inspectorate. The Secondary data sourced from primary legal materials, secondary and tertiary. As for the locations that serve as research include BKD, the Election Commission and the inspectorate in Banyumas, Purbalingga, Sukoharjo, Semarang and Surakarta. Overall the location are within the province of Central Java.

The phase of research began with a descriptive presentation of data collected, further processed and prepared based on the categorization of cases of neutrality violation. The categorized will be described and analyzed by latent content analysis and comparative analysis. To support the analysis, it used grammatical and systematic interpretation. Empirically, it carried out with the mindset of discussion and interprettation (theoritycal interpretation), where the data will be discussed with the rule of law, legal theory and legal doctrine.

\section{Discussion}

\section{Neutrality Conception of Government Emplo- yee And The Problems Application}

Philosophically, the regulation is an attempt to limit the power of the possibility of it movement over his own instincts, which ultimately leads to the abuse of power. The concept of power limitation in the state of law was stated by Plato through nomoi conception that a country in which everyone is subject to the law, including the ruler or king to prevent them from acting arbitrarily. This is in line with the conception of a democratic constitutional state that put the government which has limited powers and no right to act arbitrarily against its citizens. The

3 Tedi Sudrajat, "Implikasi Hukum Pembatasan Peran serta Pegawai Negeri Sipil Dalam Proses Politik di Indonesia”, Jurnal Dinamika Hukum, Vol 11 No. 3, September 2011, Purwokerto:Law Faculty of Jenderal soedirman University, page 417

4 Tedi Sudrajat, "Gagasan Fungsionalisasi Jabatan Dalam Rangka Reformasi Birokrasi”, Civil Service. Jurnal Kebi- idea that power should be limited is pro-posed by Lord Acton and he warned that the government is always held by a men and weaknesses is inherent in humans invariably. ${ }^{3}$

The concept of the legal restrictions is based on integration function and coordinate interests which can intersect each other and by law is integrated so it can be minimized. Organizing those interests is done by limiting and protect these interests. ${ }^{4}$ This things that can underlie the relationship between the laws with the bureaucracy, where bureaucracy can run when the law has been set in the advance in organize of the bureaucracy carried out by government employees.

Practically, the legal relationship between the state and government em-ployees is called as the public relations department. According to J. H. A. Logemann, this relationship occurs when a person binds himself to submit to the orders of the government to do something or some kind of position in performing one or several kinds of positions was rewarded with salaries and some other advantages. This means that the main of the public service relationship is an obligation for the employee to submit to the appointment in some kinds of certain positions with the result that the employee accept unconditionally appointment in the positions that have been determined by the government, otherwise the government employee entitled to appoint a person in a particular position without the need for adjustment of the concerned. ${ }^{5}$ Its the concept that underlie the emergence restrictions neutrality.

The Meaning of neutrality was not directly proportional to its application. In fact, the position of government employees can not be separated from political activity due to: first, in this reform era, every government action is always in the name of democracy. It should be underlined that the principle of political equality is a logical consequence of the principles of popular sove-

jakan dan Manajemen Pegawai Negeri Sipil, Vol. 11. June 2013, Jakarta: Badan Kepegawaian Negara, page 100

5 Logemann on S.F. Marbun and M Mahfud MD. 1987, Pokok-Pokok Hukum Administrasi Negara, Yogyakarta: Liberty, page $98-99$ 
reignty. All adult citizens, healthy in physical and spiritual are have the same rights to participate in political decision-making process of a country. Democracy principle which is based on the political equality emphasizes the equality of opportunity for all people or citizens. In this case, the political equality gives a loose place against the emergence of dissent. Throughout all the citizens have genuinely equal opportunity to participate as desired, then the political requirement of equality is achieved through the life of state and government activeties. ${ }^{6}$ Secondly, There is an uncertainty in the law relating to political rights for government bureaucracy. Should be noted that in the context of government administrators there are government employees, members of the Indonesian Armed Forces (TNI) and members of the Indonesian National Police (Polri). In practice, members of the military and police are prohibited from explicitly involved in the political process but for government employees still given space to an active participant of the campaign, has the right to vote and may be state officials through the election mechanism is heavily influenced by the interests and certain political groups. ${ }^{7}$ Observing this, the definition of neutrality for government employees are not relevant for use, as should the meaning neutral government employees are free from the influence of all groups and political parties. In the present context as the development of democratic system, political interventon is not enough if it is "just" measured from involvement or or-ganize someone as a member of a political party. Election phenomenon could be non-member example of how government employees and/or political party official atually can actively involved and used as a means political mobilization by the candidates for governor/regent/mayor won the general election. Third, apart from the political problems, there are also psychological problems

6 Hasnati, "Pertautan Kekuasaan Politik dan Negara Hukum”, Jurnal Hukum Respublica, Vol. 3 No. 1, of 2003, Pekanbaru: Law Faculty of Lancang Kuning University, page 110

7 Setiajeng Kadarsih dan Tedi Sudrajat, “Analisis Terhadap Hak Pilih TNI dan Polri dalam Pemilihan Umum”, Jurnal Dinamika Hukum, Vol. 11 No. 1, January 2011, Purwokerto: Law Faculty of Jenderal Soedirman University, page 48-61 in the concept of leadership is still using red tape patrimonial and patriarchal. It means that the patrimonial bureaucracy as a continuation and heritage of traditional values in the kingdom of the past mixed with the style of the colonial bureaucracy. Elements of local culture or cultural ethics kingdoms and modern culture mixed in a government bureaucracy that continues to grow adding to the Indonesian bureaucracy. The characteristics of patrimonial bureaucratic officials are screened on the basis of personal criteria; position is seen as a source of wealth and profits; officials control both political functions as well as administrative functions and any action directed by the personal and political relationships. $^{8}$

Observing at those three (3) issues above, a clash between loyalty and neutrality are unnecessary when there is a strengthening against the substance, structure and legal culture in the organization of the bureaucracy. In implementative, the used model is oriented on legalistic approach to the legal settlement situationally. Situational approach will be correlated with the position of government employees who have a strategic role in the governance and bureaucracy. It means that the rules remain the basis of application of the law, while the case resolved based on the consideration of the conditions and the real reason is based on the authority inherent in its status. In this case, the government should set a standards, procedures and clear criteria against violations of neutrality as a basis for the imposition of penalties that are scalable and do not provide a double standard. There is a strengthening of the legal structure requires an independent staff, objective and transparent in enforcement of penalties for neutrality violation.

8 Dede Mariana on Lili Ramli, “Masalah Reformasi Birokrasi", Civil Service. Jurnal Kebijakan dan Manajemen Pegawai Negeri Sipil, Vol 11 No. 2, November 2008, Jakarta: Badan Kepegawaian Negara; See also on Hayat, "Konsep kepemimpinan Dalam Reformasi Birokrasi: Aktualisasi Pemimpin Dalam pelayanan Publik Menuju Good Governance", Jurnal Borneo Administrator, Vol. 10 No. 1, April 2014, Samarinda:State Administration Comission, page 72 
Model of Disciplinary Enforcement against Neutrality Violation of Government Employees in The Regional Head Election in Central Java

Regional autonomy created the role of the central bureaucracy. Bureaucracy as the subject of development has a big role in the social structure, in which the bureaucracy is able to create the policy and also the direction of development which close with the areas of community life. As a logical consequence, bureaucracy has a strategic position in the map at the level of local politics. ${ }^{9}$ Based on that, the function of the government employees neutrality of to be important in order to avoid the abuse of power and authority that intervention by the political constellation in the area.

At this time, the norms of neutrality has been set inlegislation in the field of employment. When norms has been formed, further efforts is functioning the norms through the enforcement of penalties. Based on the study of disciplinary punishment enforcement mechanism in Banyumas, Purbalingga, Sukoharjo, Surakarta, and Semarang, there are similar patterns in enforcement of penalties neutrality mechanisms as indicated in Chart 1 below.

Mechanism as described in Chart 1 has the weakness of no entry of the implementing agencies (the Election Commission) and the supervisor (Panwaslu) in the structure of the enforcement of the punishment, thats why it required the interagency coordination functions relating to breach of discipline. In addition, the mechanism of punishment still rests entirely on local staff development officer (PPKD) so that the control mechanisms of the importance is unclear. On the basis of these issues, based on the study in the first year and it is equipped with the data in the second year, the authors make the models in the enforcement of penalties for breaches of discipline in chart 2.

In order to provide a clarity in the enforcement of neutrality penalties, therefore the phasing in enforcement of disciplinary punishment

9 Indaru Setyo Nurprojo, "Merit System dan Politik Birokrasi di Era Otonomi Daerah", Civil Service-Journal Kebijak- neutrality groove was made as described in the chart 3.

The groove as described in the chart 3 provides four (4) phases in the enforcement of disciplinary action include: first, Phase receipt and review of the file. At this stage, clarification is given that the report must be made in writing and be accompanied by supported documents so that search efforts indication of a violation will be faster and systematic. To facilitate the submission of the report, then the public, mass media, related local government offices and other interested parties may submit to the BKD, the Election Commission, the Election Supervisory Committee and/or the inspectorate. Inter-agency task is to perform the functions of coordination to follow up incoming reports. Second, The delegation authority phase. At this phase, the incoming file have been reviewed through coordination by four submitted to the Trustees institution of the Regional Personnel Officer (PPKD) to form Discipline Inspection and the Imposition of Penalties Team (TPPHD). The team was established through the Letter of Assignment by PPKD in which there are elements of the Election Supervisory Committee, the Election Commission, relevant SKPD, BKD, Inspectorate and chaired by the Regional Secretary. Third, the examine of the substance phase. Examine the substance is done by calling the witnesses and reported, file examination, the witness, reported and other supporting data. Standards, procedures and criteria for the determination of infringement is based on Government Regulation No. 53 of 2010 on Discipline PNS, sociological reasons and how big the legal implications in violation of agency offenders. The role of deputy head of the region is to provide legal consideration to its recommendations will be given by TPPHD. Fourth, the establishment phase of TPPHD decision. The result of the recommendations are final and binding upon the determination that will be provided by PPKD. If PPKD differing views with TPPHD, then deputy head of the region to serve as a facilitator of coordination between TPPHD with 

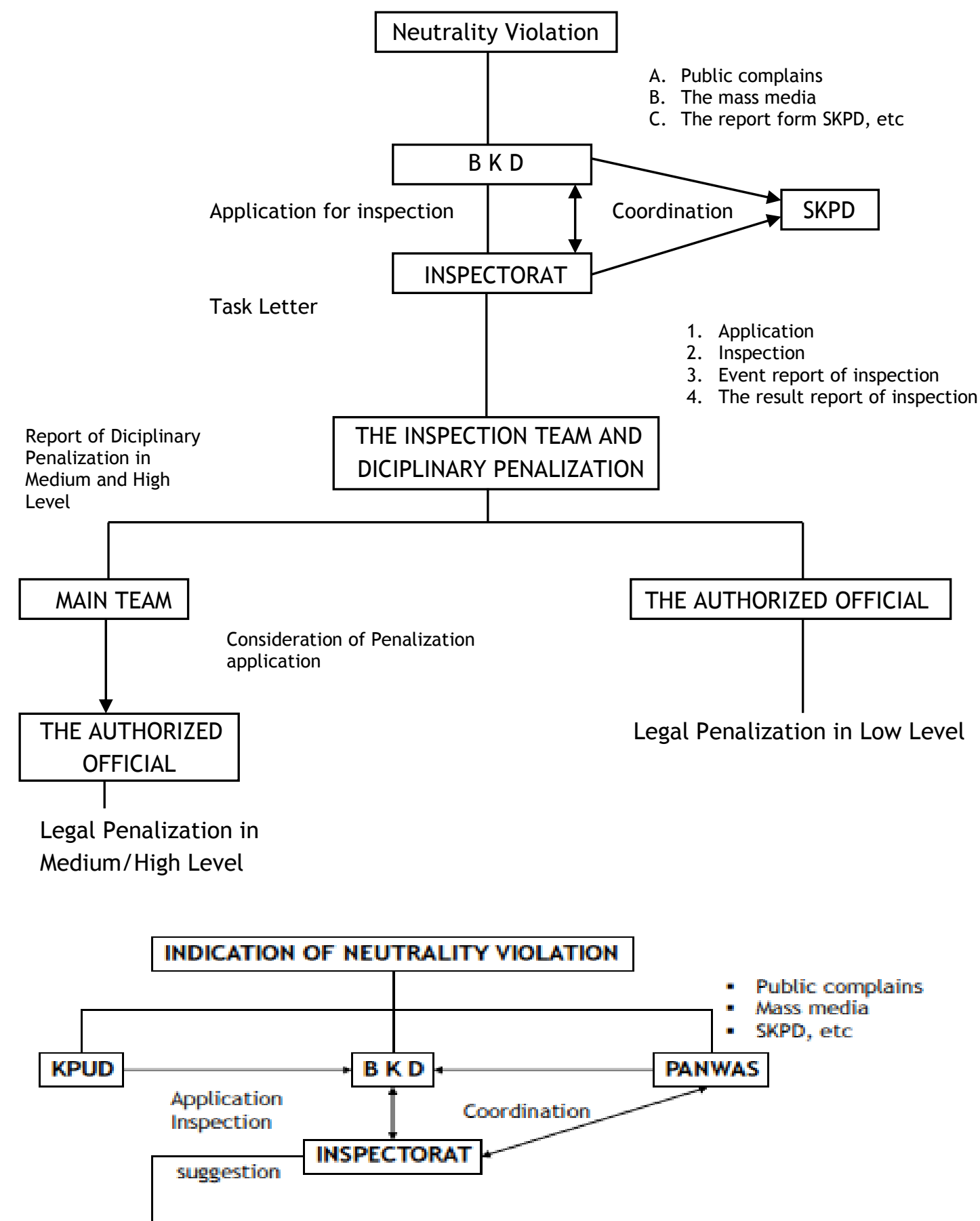 \begin{tabular}{c|c} 
THE AUTHORIZED \\
OFFICIAL
\end{tabular}
- Document Examination, Sanction, and others
- Identification and Qualificationof Violation
- BaP
- LHP
- Recomendation of Diciplinary Penalization

INSPECTION AND DICIPLINARY PENALIZATION TEAM
Consideration

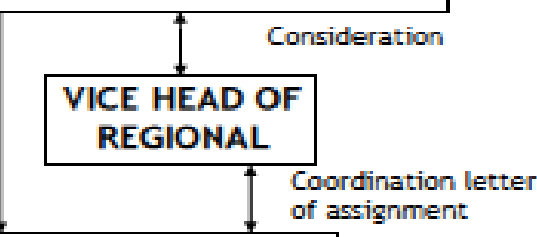

EMPLOYEE SUPERVISING OFFICIAL

Legal Penalization 


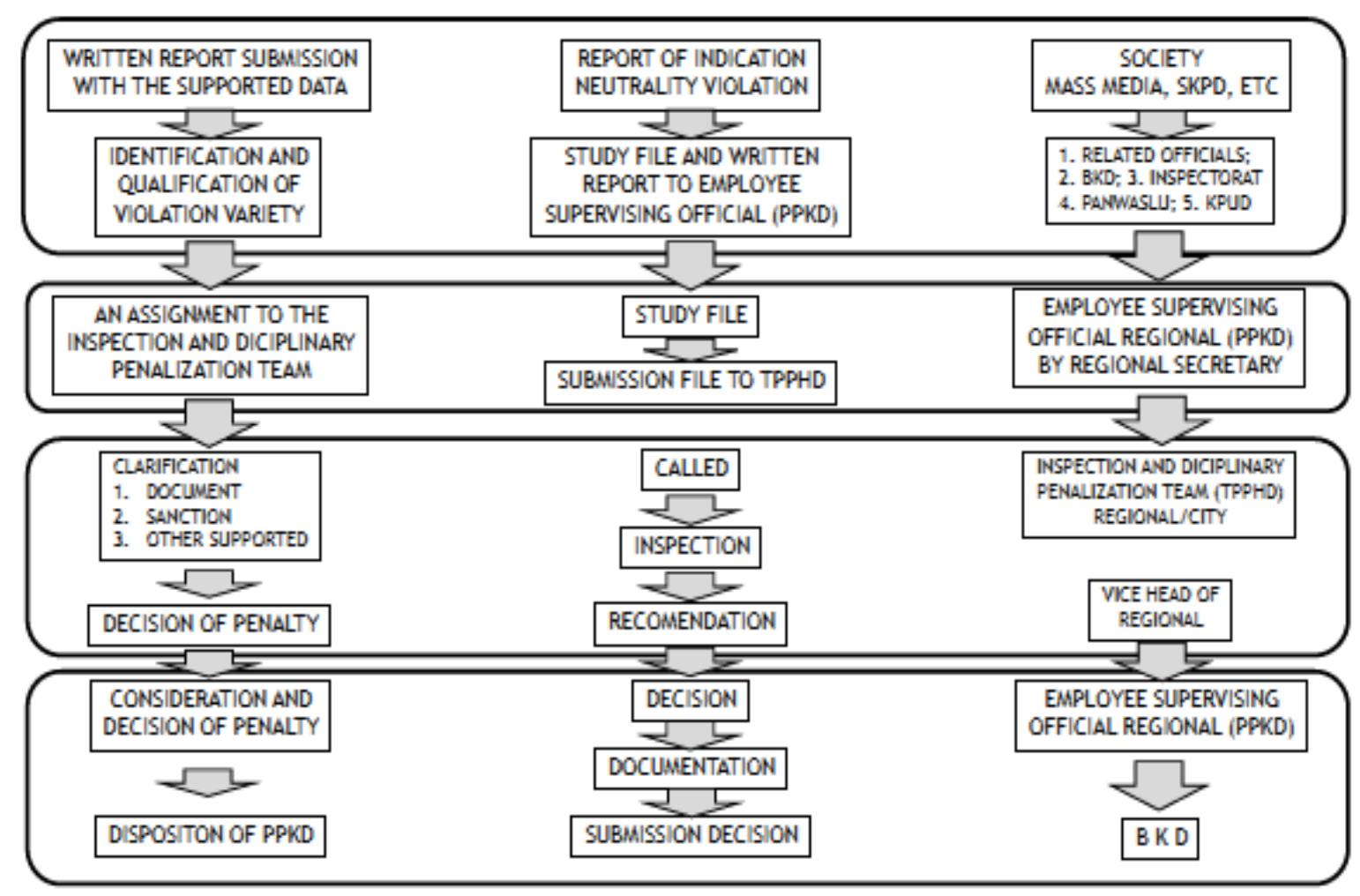

PPKD. The verdict stated publicly after the filing by BKD. When there is a sentencing through a decree (SK), legal mechanisms that can be used is through Administrative Court. This means that there are still other legal remedy outside of the government's internal mechanism to test the validity of the decree as part of the disputed staffing in the Administrative Court.

Observing the flow of the chart above, the proposed model in the enforcement of penalties for neutrality violation is focused in interagency coordination. The function of coordination between TPPHD, deputy head of the Regional and PPKD will minimize the intervention of political interests. In addition, strengthening the role of TPPHD in providing recommendations form the basis of objectivity in the enforcement of penalties neutrality violations.

\section{Closing}

\section{Conclusion}

PNS is a civilian state apparatus in charge of implementing legislation, enforcing laws and regulations, provide public services based on the principle of impartiality (impartiality), collect and process information as input material preparation and formulation of policy recommendations to the government. Therefore, the existence of the principle of neutrality has a strategic role to prevent abuse of power and authority, and to realize the climate of fair competition and is equivalent to eliminating fraud structured using state facilities and relationships authority. When the violation happen, it would require the government's efforts to create standards, procedures and criteria for the objective and transparent use legalistic approach oriented handling casuistry and situational.

\section{Recommendation}

The authors propose a model enforcement of penalties for violation of neutrality in the General Election in accordance with statutory provisions and the inherent authority of each institution. The functions of coordination, clarity of authority, mechanisms and decision binding sentencing recommendation is expected to be the answer to the issue of enforcement of penalties neutrality. In addition, the role of deputy regionnal heads raised to strengthen the role of the fa- 
cilitator TPPHD and when there is a difference with PPKD. In order to create legal certainty, the proposed model can be used as a reference enforcement punishment and needs to be arranged in the form of the decree.

\section{References}

Hartini, Sri. Setiajeng Kadarsih and Tedi Sudrajat. "Kebijakan Netralitas Politik Pegawai Ne-geri Sipil dalam Pemilukada (Studi di Ja-wa Tengah)". Padjadjaran Jurnal Ilmu Hukum. Vol. 1 No. 2. December 2014. Bandung: Law Faculty of Padjadjaran University;

Hasnati. "Pertautan Kekuasaan Politik dan Negara Hukum". Jurnal Hukum Respublica. Vol. 3 No. 1 of 2003. Pekanbaru: Law Faculty of Lancang Kuning University;

Hayat. "Konsep kepemimpinan dalam Reformasi Birokrasi: Aktualisasi Pemimpin dalam Pelayanan Publik Menuju Good Governance". Jurnal Borneo Administrator. Vol. 10 No. 1 April 2014. Samarinda: State Administration Comission;

Kadarsih, Setiajeng and Tedi Sudrajat. "Analisis Terhadap Hak Pilih TNI dan Polri dalam Pemilihan Umum". Jurnal Dinamika Hukum. Vol. 11 No. 1 January 2011. Purwokerto: Law Faculty of Jenderal Soedirman University;
Marbun, S.F. and M Mahfud MD. 1987. Pokok-Pokok Hukum Administrasi Negara. Yogyakarta: Liberty;

Nurprojo, Indaru Setyo. "Merit System dan Politik Birokrasi di Era Otonomi Daerah". Civil Service. Jurnal Kebijakan dan Manajemen Pegawai Negeri Sipil. Vol. 8 No. 1 June 2014. Jakarta: State Employee Department;

Prasodjo, Eko and Laode Rudita. "Undang-Undang Aparatur Sipil Negara; Membangun Profesionalisme Aparatur Sipil Negara". Civil Service. Jurnal Kebijakan dan Manajemen Pegawai Negeri Sipil. Vol. 1 June 2014. Jakarta: State Employee Department;

Ramli, Lili. "Masalah Reformasi Birokrasi". Civil Service. Jurnal Kebijakan dan Manajemen Pegawai Negeri Sipil. Vol 11 No. 2. November 2008. Jakarta: State Employee Department;

Sudrajat, Tedi. "Gagasan Fungsionalisasi Jabatan Dalam Rangka Reformasi Birokrasi”. Civil Service. Jurnal Kebijakan dan Manajemen Pegawai Negeri Sipil. Vol. 11 June 2013. Jakarta: State Employee Department;

"Implikasi Hukum Pembatasan Peran Serta Pegawai Negeri Sipil Dalam Proses Politik di Indonesia". Jurnal Dinamika Hukum. Vol 11 No. 3 September 2011. Purwokerto: Law Faculty of Jenderal Soedirman University. 